\title{
Branding - Power to Change Business Modality
}

\author{
Sarita Khadka (Karki) \\ Associate Professor, Nepal Commerce Campus
}

\begin{abstract}
Branding refors to the strategic decisions and actions intended to create and maintain the firm's product or service concept in customer's mind. The form selects some of the key differentiation factors on which it has competitive advantage and establishes the image so that customers view the product or service as different. The projected image is crucial and what the firm does to the mind of customer's more important than what the firm does to the products. Nepal is ideally referred to as small market in terms of business generation, however more today Nepali market is flooded with international brands. But Nepal has extreme good brands and marketing practitioners as well they have been to create and establish amazing local brands. It also creates opportunities explain the growth of branding and marketing as a career option for the new generation.
\end{abstract}

\section{Introduction}

The term of branding has come no longer about 'marking' - it means more than stamping. You brand a product, a service or your name. Once you brand a certain something you set a benchmark of expectations, that people who use your product or service can anticipate. Today with technology change is extraordinarily fast. Some 50 years ago, when brands were evolving there was time to playout a character or strategy. Now the journey of a brand is quite differents if you get it wrong you could become irrection that fits strategically and tactically. It means not being afraid to fail, quickly adapting and moving on without regrets. Thus, branding is related with human evolution and civilization.

\section{Methods to choose brand name}

If you have ever attempted to name a company you know that the process can be grueling. First the best domain names were baken - as of 10 years ago. If you want to name your company after something common, in the English language, you will need to be prepared to spend upwards of tens of thousands of dollars to lay claim to your web presence. Then, there's the question of trade mark. You could go through the effort of namely your company think about the concepts that you learned in your high 
school English classes, including alternation, assonance, interjection and consonants. Thus brand perception does matter. But what is more important is how you create and position that perception among your customers studies have shown that 75 percent of purchase decisions are based on emotion. The organizations that place value - over price considerations to win hearts are usually armed with a well defined, genuinely likeable brand. The benefits of defining your organization is values voice and market placement can include increased profits and better customer and employee retention. Here are some effective ways to begin defining your organization or important your current branding efforts:

\section{1) Tap into the power of symbolism and sounds:}

Certain sounds inspire positive emotions and result in experiences that are likely to be liked, remembered. When choosing your brand name, think about the words that youi are using in everyday life.

\section{2) Use memorization techniques to find concepts:}

The best company are emotion driven and memorable as a result. It you are struggling to name your company, stop loser faces on what you want your company, think about the emotion that you want your target customer to feel, start by creating a mind map of the concepts related to your business. Explore descriptive words, emotions and experiences that you have felt in building your business or brand. From there make an outline of the visual images associated with your company.

\section{3) Become a lexical innovator:}

If you cannot find a word that perfectly captures the essence of brand, invent your own. Words are ever changing and follow evolutionary cycles. There are new words, slang or formal, entering the market, all the time. A readily appearent examples of trend is Google - a word that arose from complete obscurity to eventually earn its place in oxford Dictionary. This was a company that walked away from. What was common and known to test a completely new concept. Reader encourages founders, brand managers and other professionals responsible for naming to venture - out - side of their comfort lines. Explore slang that communities are using and ask new audiences to describe your brand from a cased, authentic perspectives. Innovation and progress come from venturing into new teirian. Your business name should be no different from your product or service - ask people to give words to your brand with a fresh pair of eyes.

\section{4) Be authentic}

A well branded organization has the ability to be recognized, earn loyalty and define themselves within their market. However your efforts to brand your organization would not get far it they are not authentic. Donot try to cast your brand on luxury, if you serve price. Sensitive customers. Avoid being too 'fun' if youir ideal customers tend to be more serious. You will struggle to deliver the right consistency across platforms 
if your brand is nothing more than a facade.

\section{5) Build from the inside - outside}

Consumers trust their friends and families opinion for more than even your owned media assets. That's why every effort to brand your business should include thought toward building a tribe. Who will spread you word organically and with a healthy close of authentically. Start your branding efforts with the people closest to you which will most likely be your employees, your existing supporters and their friends. By building excitement around your massage with the people who already know and love your brand, the word will spread more quickly.

\section{6) Define your archetype:}

While the concept of archetypes may have been defined by famed psychologist, the idea is nearly as old as time. This tactic's been used successfully by major brands than you probably realize. While a basic archetype doesnot need to control your brand's entire identify figuring out where you fit into the classic narrative can significantly streamline your process of creating a competing brand story.

\section{7) Be Relatable}

Virually everyone knows their company should be relatable, but too few understand what that really means the world's most relatable brands have made it their mission to understand their Customer's problems and focus on being the defect solution. That is why Nike represents athletic tramps and Geico represents price sensitively.

\section{8) Market to your customers:}

If your current content marketing strategy doesnot include outreach efforts for your existing customers, you are losing fabulous potential. Banding your clients who you are, and how you fit into their unique life style in order to remain both top of mind and avoid being forgettable. Strategist Daniel Tayhighlights the fact that treely epic brands are not build overnight but more usually over decades with the help of consistent efforts.

\section{9) Be honest about what you donot do well:}

Regardless of what makes your brand unique, your values need to include authenticity which is enhanced by honesty know what your company doesnot do well, and focus on enhancing your strength when things go bed you have to be honest about the reality and do everything human by bossible to fix it.

If your organization doesnot have a non-profit or humanitarian bent, engaging your community in positive and altruistic ways can be an incredible branding action. 
Whether you choose to donate aportion of your profits or sponsor employee Led Volunteer outreach it's more than just good public relation community service can enhance your customer's perception of your brand and improve your ability to leverage your employees as brand ambassadors.

\section{Branding Strategies}

There is no need to reiterate that your brand is your identify. However maintaining this identify in the rapidly changing market trends could be very challenging. You may already the following the latest branding trends 2017, however those branding strategies that are still a part of your marketing comparing may not be as effective today. Here are some branding strategies that you should get rid of as soon as possible.

\section{Branding is more than just taglines and logos}

The concept of rebranding previously revolved around redesigning your logo and introducing a new tagline. However the introduction of social media and the transfer of advertising and public communication from hoardings, bill boards and TVC to social not working sites have redefined the concept of branding. Now, the brand image depends on market reputation and customer feedback more just taglines and logos.

\section{Branding without social media content marketing}

Social media content marketing has offered countless opportunities to multinational corporations. Some of the opportunities include sending the some message in a variety of ways, introducing new products to global audiences, creating a brand image and gathering customer feedback. If social media content marketing is not included in your branding strategy, then it is time to review it.

\section{Relying on inconsistency}

One of the most common branding trends back in the day was to introduce something unique and different to get noticed. However establishing or expanding your customer base primarily depends on consistency based marketing strategies. For example Nike promises comfort and has introduced a wide range of shoes adhering to health problems. Consistency is essential to build familiarity with the brand and establish loyal customer bases.

\section{Using Inappropriate Graphics and Virtual Mistakes}

Designing a non vector logo using irrelevant colours on your website, and using a website that is not mobile optimized are some virtual world mistakes that may make you lose your leads. Going an extra mile to hire a professional website developer or graphic designer is definitely worth the effort.

\section{Prioritizing Products Over Customer Services}

WhileWal -Mark introduced the concept "Customer is Always Right", however 
many companies continue to make the mistake of prioritizing their products over customer services. In present world the power of a brand lies its satisfactory customer services. Training your customer service representatives and establishing online customer response centers are the initial steps you need to take while remodeling your brand strategy.

\section{Not Associating the brand with Human Emotions and Needs}

Human emotions and needs are now directly or indirectly associated with monetary terms like time and cost effective shopping deals. You need to humanize your brand by associating it with human emotions and needs while remodeling your brand strategy.

\section{Skimping on the Marketing Budget}

Branding is the Strongest tool for your business in competitive markets. Therefore, skimping on the marketing budget to save on the production costs in a mistake that could cost you a fortune.

\section{References}

Koirala, K.D. (2014). Marketing Management, M.K. Publishers and Distributors, Kathmandu. Khadka, S. (2010). Fundamentals of Advertising, Buddha Publication, Kathmandu.

Shrestha, P. (2016). Fundamentals of Advertising, Sansana Publication Pvt. Ltd. Kathmandu. Thapa, G. \& Thapa, B. (2016), Branding Management, Khanal Publications Pvt. Ltd. Kathmandu. The Himalayan Times, perspectives, Friday, August II, 2017.

The Himalayan times perspectives, Sunday, September 24, 2014.

The Kathmandu Post, Money, Wednesday, December 13, 2017. 